Religious Studies 42, 291-297 ( 2006 Cambridge University Press doi:10.1017/S0034412506008456 Printed in the United Kingdom

\title{
A response to Cordry on design
}

\author{
MARK WYNN \\ Department of Theology, University of Exeter, The Queen's Drive, Exeter, EX4 4QJ
}

\begin{abstract}
In his paper 'Theism and the philosophy of nature', Ben Cordry argues that theism's conception of nature has been falsified. In this response, I argue that the universe in many ways conforms to theistic expectations, and that there is no presumption that a divinely ordered world will take the form that Cordry proposes.
\end{abstract}

In his paper 'Theism and the philosophy of nature', Ben Cordry offers a range of well-argued and thought-provoking observations on the argument from design. ${ }^{1}$ In this response, I shall concentrate on what I take to be his central thesis: our world lacks various features that one would expect to find in a designed world, and this fact provides powerful evidence against theism.

\section{Are Cordry's marks of design displayed in our cosmos?}

Unlike many critics of the design argument, Cordry allows that it is easy enough to specify the differentiating features of a designed universe. And he gives as examples of such features, repetition of themes ('a melody may be repeated and varied throughout a song', 274) and resemblance ('in the case of Stonehenge the blocks were worked to resemble each other in size and shape', 274), as well as two more examples that I do not have space to consider here (external reference and self-conscious play).

The advocate of design is likely to suppose, of course, that these marks are in fact abundantly displayed in our cosmos. Science and common sense alike reveal that the universe exhibits a high degree of temporal regularity (which in turn makes for repetition and variation) and that it is comprised of things which exist by kind (there is, for example, a relatively small set of kinds of fundamental particle). So to this point, the proponent of design is likely to suppose that Cordry has in effect provided a prima facie case in support of design: the universe exhibits not just here and there or now and again but pervasively qualities which by his reckoning should count as marks of design. 
But Cordry is more interested, of course, in various other phenomena, which on his account will also rate as marks of design, but which are absent, he thinks, from our world. And he maintains that the failure of the universe to display these further marks of design suggests overall that it is not designed. Let's consider this case.

\section{Cordry's preferred marks of design}

Cordry lists various respects in which the universe fails to suggest design. For example:

It is a meaningless fact that the earth is the third planet from the sun and that it has exactly one moon.... The craters of the moon have no aesthetic pattern and carry no message. The geography of the earth does not seem to be designed: the continents aren't intentionally shaped .... . (278)

And the reader is invited to suppose conversely that if the world were designed then we would expect to find facts of this kind: the shape of the continents resembles some of the patterns found on the moon; the earth has three moons, and three continents, and is the third planet from the sun (a pattern which would suggest that the number 3 is significant for the designer); and so on for various other features of the solar system and the wider cosmos. What should we make of this case?

Let us allow that features of this kind would indeed be marks of design, and let us allow that our cosmos does not exemplify such features. But why suppose that the absence of these features is a mark of the absence of design? My own initial response is to think that a world which exhibits Cordry's favoured marks of design would be rather 'gimmicky', and so on aesthetic grounds there is no reason to expect God to make such a world. But let me try and offer a more argued response to his case.

\section{Should we expect Cordry's preferred marks of design?}

Christians (and adherents of the other major theistic faiths) standardly suppose that religiously deep knowledge of God depends upon transformative or evaluative encounter of some sort - such knowledge is realized through the consciousness of sin, and of God as calling the person to renewal of life, or through an awareness of the moral claim that is made upon us by other human beings, or through our encounter with mundane beauty, where such beauty is taken as an intimation of a deeper and as yet not fully disclosed Beauty. Obviously this is to offer a very large generalization about the character of Christian experience, but it is one which seems broadly consistent with Protestant as well as with Catholic and Orthodox sensibilities. This picture is, of course, connected with the idea that God is the supreme value, and that genuine 
religious understanding involves not just verbal knowledge of this fact, but being engaged by the divine goodness: someone who comments nonchalantly 'Yeah sure, God exists', or 'Yeah sure, God is good' has, from the Christian point of view, no real knowledge of God at all. Real knowledge implies, rather, a deepseated, identity-defining appreciation of (or at least reckoning with) the divine goodness.

If this is so, then we might wonder whether it makes sense to suppose that a 'revelation' whose sense can be grasped independently of any evaluative engagement could offer a religiously deep understanding of God. And we might even suppose that such a revelation would run the risk of deceiving us about God, insofar as it could be taken to imply that genuine knowledge of God is possible apart from any evaluatively engaged response.

Now, there is, I take it, no evaluative commitment implied in an inference from, for instance, the shape of the continents or the galaxies to the idea of design. And we may doubt therefore whether the Christian God would have a powerful, let alone an overriding, reason to ensure that any universe which He makes will display this sort of manifestation of design. This is not so much because such a mark of design would compromise human freedom by making God's reality too evident (the response that Cordry attributes to Swinburne) but rather because it is unclear whether it could offer, or provide a route to, religiously deep knowledge of God (there is a sense then in which such a 'revelation' would not make God's reality evident enough). But if there is reason to doubt whether a theistically designed universe would take the form that Cordry has described, then we cannot take the absence of his favoured marks of design to be evidence of the absence of divine design.

So to summarize our discussion to this point, it seems to me that Cordry makes too much of the absence of certain localized marks of design (the shape of continents or of galaxies, for example) and not enough of the presence of various universe-wide marks of design (temporal regularity, for example) - for there is no compelling reason to expect marks of the first kind in a theistically designed universe, and marks of the second kind are, by Cordry's own reckoning, indicative of design. This account invites expansion on various points. Let me consider three.

\section{'Objective' marks of design and relationship to God}

It might be said: 'There are surely plenty of examples from Christian history of figures of paradigmatic sanctity who nevertheless believed that there was overwhelming evidence of design of precisely the kind that Cordry has described - so the provision of such evidence cannot after all be a bar to genuine faith, and may even be a requirement for it?'. I agree, of course, that many Christians of undisputed sanctity have taken the existence of God to be provable 
independently of any evaluative engagement - after all a good deal of natural theology has proceeded along these lines. However, I have not maintained that belief in the availability of 'objective' evidence cannot be combined with genuine sanctity - only that the real driver of genuine sanctity is moral and aesthetic or, in general, evaluative engagement. And if that is so, then a world in which there is not manifest and 'objective' proof of design is not evidently a world that will frustrate the purposes of the Christian God - providing that such a world provides opportunity for the kind of moral and aesthetic engagement that is a condition of a religiously deep understanding of God.

It may be objected: 'But surely the God of the tradition would wish not simply to realize various necessary conditions for relationship to himself but to actualize such a relationship - and won't that depend upon the believer having good evidence for the existence of God, and couldn't that evidence be provided by way of Cordry's marks of design?'. But perhaps moral and aesthetic engagement is not just preparatory to relationship to God but itself a mode of relationship to God. The objection from divine hiddenness, of which Cordry's argument seems to be a special case, often appears to suppose that relationship to God is best understood as a kind of one-to-one interaction. Granted that model, a question arises about why we cannot identify God considered as a particular individual (of the kind who communicates with us via localized marks of design, rather as other human beings do). But perhaps relationship to God is better conceived as love of the Good. And perhaps the Good is loved, and genuinely encountered, in loving its instances. To put the point in Simone Weil's terms (and she is speaking here for a much larger tradition, of course), why not suppose that: 'In everything which gives the pure authentic feeling of beauty there really is the presence of God'? If that is so, then even if a revelation which involves Cordry's marks of design were to disclose the existence of a particular individual, to whom we might be related on the basis of some one-to-one interaction, this would be religiously speaking of no great interest - in such a universe, relationship to God would still be mediated by way of moral and aesthetic encounters of the kind that are abundantly available in a universe such as our own.

\section{'Objective' marks of design as mediating an evaluatively engaged response}

It might be wondered: 'Isn't it a mistake to see Cordry's case as hinging solely upon phenomena (such as the shape of the continents) which do not invite an evaluatively engaged response?'. For instance, if we were to discover that the universe is geocentric, wouldn't this discovery tend to elicit a response of awe and gratitude? Let us allow that it would. However, if Cordry is to make his case, he needs to identify phenomena that God would have very powerful reason to bring about in any universe that He makes - otherwise there will be no reason to take 
the absence of such phenomena to indicate an absence of theistic design. And why think that the earth's location at the centre of the universe is such a phenomenon? After all, there are other ways of eliciting a response of awe and gratitude (indeed many have responded in this way to the discovery that our earth is located where it is, and came to be as it did).

To establish Cordry's thesis, it is not even enough to show that a universe which has the earth at its centre (to keep to this example) is better than other kinds of universe, ceteris paribus. For in that case, it will remain possible (to take just one line of response) that God (understood in traditional terms, as a generous God) has chosen to make a variety of cosmoses, each with its own distinctive goods, and that our universe, while inferior to some other kinds of cosmos, is one such cosmos.

\section{Christian theology and the structure of the cosmos}

Finally, it may be objected: 'Surely theism has historically been associated with a teleological or geometrical theory of nature, so doesn't the discovery that nature is not after all to be understood in these terms damage theism, at least in part?'. It is true that many Christian theologians of earlier centuries did suppose, for instance, that the universe should have an elegant geometrical structure. To give just one such case, the Cathedral School of Chartres, in the twelfth century, depicted God as 'a master builder, a theoreticus creating without toil or effort by means of an architectural science that is essentially mathematical' ${ }^{3}$ But these Platonizing Christians would not have been disappointed, I think, by modern discoveries of the universe's architecture - have we not come to learn after all that mathematics is the language of nature? Similarly, while developments in science may have put paid to the geocentric picture of the universe, they have also dramatically confirmed that, in a sense, the large-scale structure of the universe does pick out life as 'centrally' important (I am thinking here of fine-tuning discoveries, of course).

So while it is true that fundamental science does not appeal to final causes, the basic structural features of the cosmos which science itself reveals (its mathematical intelligibility and its fine-tunedness, for example) can readily be understood in teleological terms - and to this extent the expectations of theistic philosophies of nature have been fulfilled. Moreover, as with regularity over time, so here we may wonder whether there is a good naturalistic account of these facts. If there is not, then it is not just that theistic expectations are confirmed in these respects, but that naturalistic expectations are overturned.

Moreover, any account of whether the universe is teleologically structured should take into account not just the world's character as it appears through the lens of the sciences, but also the phenomenology of human experience. And it is surely striking that human beings have, repeatedly, found close engagement with 
nature to be a source of religious wonderment. Again, this is unsurprising on a theistic view of nature, but not obviously to be expected otherwise.

Take for instance Emile Kohák's account of his experiences of living in close proximity to nature:

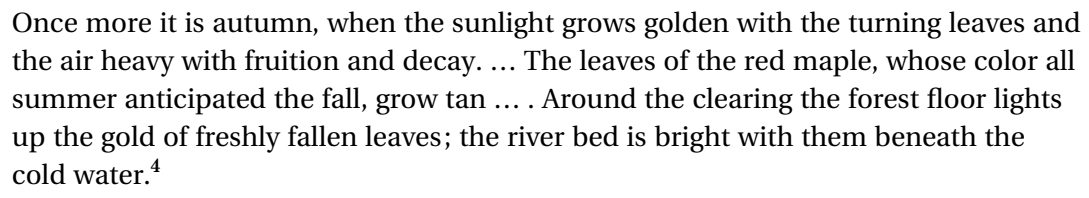

Now while this scene is of course describable mathematically in the language of physics, the felt content of the experience cannot be captured in such terms, and what this content suggests, according to Kohák, is this: 'The ultimate sense of being is the ingression of the Idea of the Good ... into matter and time, becoming actual within them and bestowing meaning upon them. ${ }^{5}$ Of course, this is not exactly an argument for a teleological view of nature, but it does suggest that if we are to reach a verdict on the plausibility of Cordry's case we will also need a phenomenology of nature (something that some earlier theologians may have overlooked just because of their tendency to prize mathematical over other kinds of intelligibility). This is, however, to take the assessment of his case outside the bounds of 'philosophy' in the usual sense.

\section{Conclusions}

Ben Cordry's paper poses a genuine question to Christian theology. Sometimes, Christian theologians have entertained quite specific expectations about the cosmos's character on theological grounds, and many of these expectations have been falsified. To give just one example: 'Even in the late eighteenth century, a scientist of the stature of James Hutton would admit to only two dry areas on the earth's surface .... Empirical evidence on the extent of deserts ... was overlooked in the interest of maintaining a reassuring physicotheological theory of the earth. ${ }^{\prime 6}$ But against Cordry I have been arguing, first, that the universe does in many respects conform to theistic expectations (given its regularity over time, consistency with life, and its beauty, understood mathematically and phenomenologically, for example). In these respects there is indeed a prima facie case for design. Moreover, the fact that other features that would also be suggestive of design are absent is not telling evidence against the hypothesis of theistic design, because God as traditionally characterized would not have a powerful reason to bring about these further marks of design.

Cordry is struck by the thought that theists have held rather definite expectations concerning the structure of nature. But of course, they have also tended to suppose that our knowledge of God's ways is attended by at least a degree of obscurity and indeed reversal of expectation - not least because, once more, 
genuine understanding of God calls for moral and aesthetic engagement and a correlative gradual education of desire and 'vision'. If this is so, then we may wonder again whether theism is committed to precise expectations concerning, for example, the location of the earth. This point too was grasped in the Middle Ages, at Chartres as elsewhere - for while Chartres Cathedral may stand as a testament to the medievals' association of theism with a particular, integrated picture of creation, the labyrinth placed at its entrance registers a question about any over-detailed anticipation of the divine ordering of things:

The way the labyrinth stretches the full breadth of the nave as one enters means that sight of it cannot possibly be circumvented .... [The labyrinth] ... was chosen [as an image of the journey of faith] because not only does it make the journey inevitably an experience of dislocation but also, unlike the maze, one in which God could be trusted to appear, in part precisely because of that dislocation. ${ }^{7,8}$

\section{Notes}

1. Benjamin S. Cordry 'Theism and the philosophy of nature', Religious Studies, 42 (2006), 273-290. Page numbers cited in the text are from this article.

2. Simone Weil Gravity and Grace, Emma Craufurd (tr.) (London: Routledge \& Kegan Paul, 1972), 137.

3. Otto von Simson The Gothic Cathedral: The Origins of Gothic Architecture \& the Medieval Concept of Order (London: Routledge \& Kegan Paul, 1956), 31.

4. Erazim Kohák The Embers and the Stars: A Philosophical Enquiry into the Moral Sense of Nature (Chicago IL: University of Chicago Press, 1984), 217.

5. Ibid., 197.

6. Yi-Fu Tuan 'Desert and ice: ambivalent aesthetics', in Salim Kemal and Ivan Gaskell (eds) Landscape, Natural Beauty and the Arts (Cambridge: Cambridge University Press, 1993), 141. Nonetheless, deserts have been found to be deeply suggestive religiously, notably in the tradition of desert monasticism.

7. David Brown God and Enchantment of Place: Reclaiming Human Experience (Oxford: Oxford University Press), 234.

8. I would like to thank Peter Byrne and Ben Cordry for some very helpful comments on an earlier draft of this essay. 